\title{
Scrotal thermographic profile and seminal characteristics of Mangalarga Marchador stallions bred in the Atlantic Rainforest biome
}

\author{
[Perfil termográfico escrotal e características seminais de garanhões Mangalarga \\ Marchador criados no bioma Mata Atlântica] \\ W.M. Machado ${ }^{1}$, C.H.S.C. Barros ${ }^{2}$, S.V. Matarazzo ${ }^{1}$, P.P.N. Snoeck ${ }^{1}$ \\ ${ }^{1}$ Universidade Estadual de Santa Cruz - Ilhéus, BA \\ ${ }^{2}$ Centro Universitário INTA - Sobral, CE
}

\begin{abstract}
The objective of this study was to determine the scrotal thermographic profile and to verify the influence of temperature and humidity of the humid tropical climate on testicular temperature and seminal quality of Mangalarga Marchador stallions. The thermal profiles of the proximal, middle, and distal zones of the testicles and total surface temperature (TSTT) were recorded using an FLIR E60bx thermal imager. The average air temperature $\left({ }^{\circ} \mathrm{C}\right)$ and relative humidity $(\%)$ were obtained $1,5,9,33$, and 66 days before semen collection and showed a mean value of $26.5 \pm 2.4$ and $80.4 \pm 6.0$ respectively. The scrotal surface temperature was close to $34^{\circ} \mathrm{C}$ and there was no variation with the age of the stallion, reproductive activity, and characteristics of the ejaculate $(\mathrm{P}>0.05)$. The only significant correlations obtained were between TSTT and minor defects $(\mathrm{R}=0.41 ; \mathrm{P}<0.05)$, between TSTT and total defects $(\mathrm{R}=0.46 ; \mathrm{P}<0.01)$, and between TSTT and percentage of morphologically normal sperm $(\mathrm{R}=-0.46 ; \mathrm{P}<0.05)$. It was concluded that the Mangalarga Marchador stallions maintained the testicular temperature within favorable conditions for spermatogenesis, demonstrating the efficiency of testicular thermoregulation mechanisms in the Atlantic Forest biome.
\end{abstract}

Keywords: horses, testicles, thermograms, air temperature, relative humidity

\section{RESUMO}

O objetivo deste estudo foi determinar o perfil termográfico escrotal e verificar a influência da temperatura e da umidade do clima tropical úmido na temperatura testicular e na qualidade seminal de garanhões Mangalarga Marchador. Os perfis térmicos das zonas proximal, média e distal dos testículos e a temperatura da superficie total (TSTT) foram registrados usando-se um termovisor FLIR E60bx. A temperatura média do ar $\left({ }^{\circ} \mathrm{C}\right)$ e a umidade relativa (\%) foram obtidas um, cinco, nove, 33 e 66 dias antes da coleta de sêmen e apresentaram valor médio de 26,5 $\pm 2,4$ e 80,4 $\pm 6,0$, respectivamente. A temperatura da superfície escrotal foi próxima $a 34^{\circ} \mathrm{C}$, e não houve variação com a idade do garanhão, a atividade reprodutiva e as características do ejaculado $(P>0,05)$. As únicas correlações significativas obtidas foram entre TSTT e defeitos menores $(R=0,41 ; P<0,05)$, entre TSTT e defeitos totais $(R=0,46$; $P<0,01)$, e entre TSTT e porcentagem de espermatozoides morfologicamente normais $(R=-0,46 ; P<0,05)$. Concluiu-se que os garanhões Mangalarga Marchador mantiveram a temperatura testicular dentro de condições favoráveis para a espermatogênese, demonstrando a eficiência dos mecanismos de termorregulação testicular no bioma Mata Atlântica.

Palavras-chave: cavalos, testículos, termogramas, temperatura do ar, umidade relativa

\section{INTRODUCTION}

Climate change and global warming trigger changes in air temperature, relative humidity, and precipitation, providing thermal stress that implies serious consequences for animal health and welfare (Lacetera, 2019). Thermal insults on the scrotum result mainly from heat waves, which directly affect the spermatogenesis cycle, because the mechanisms involved in maintaining scrotal temperature begin to fail under conditions of thermal stress for several consecutive days

Recebido em 15 de outubro de 2020

Aceito em 9 de fevereiro de 2021

E-mail: machadowm.vet@gmail.com 
(Lees et al., 2019). In males, most testicular problems are related to individual's incapacity to maintain testicular temperature within physiological parameters. The increase in testicular temperature may induce testicular degeneration and loss of germline cells via apoptosis or necrosis, with impaired male fertility (Vieira et al., 2018).

It is possible to consider equines having a substantial challenge in maintaining testicular temperature around $35^{\circ} \mathrm{C}, 3$ to $4^{\circ} \mathrm{C}$ below body temperature, to ensure efficient spermatogenesis (Alvarenga and Papa, 2009) face expected climate changes. Reproductive performance is an excellent indicator of the economic value of stallions. Digital infrared thermography stands out for being a non-invasive, non- stressful, and painless diagnostic technique to monitor animal scrotal surface temperature. It is also described as complementary to andrological examination in horses and various other species (Kastelic et al., 1996; Ramires-Neto et al., 2013; Lloyd-Jones et al., 2015; Menegassi et al., 2017; Ahirwar et al., 2018).

This thermal mapping can facilitate the detection of initial subclinical problems that result from changes in thermoregulation (Lloyd-Jones et al., 2015), since the increase in scrotal temperature influences the appearance of sperm abnormalities (Ahirwar et al., 2018). Thus, this experiment was performed to determine the scrotal thermographic profile of Mangalarga Marchador stallions bred in the Atlantic Forest biome and to verify its correlation with air temperature, relative humidity, and seminal quality.

\section{MATERIALS AND METHODS}

The experiment was conducted in the cities of Coaraci (Latitude: $14^{\circ} 38^{\prime} 27^{\prime \prime} \mathrm{S}$ and Longitude: $39^{\circ} 33^{\prime} 04^{\prime \prime} \mathrm{W}$ ), Itabuna (Latitude: $14^{\circ} 47^{\prime} 08^{\prime \prime} \mathrm{S}$ and Longitude: $\left.39^{\circ} 16^{\prime} \quad 49^{\prime \prime} \mathrm{W}\right)$, Itajuípe (Latitude: $14^{\circ} 40^{\prime} 41^{\prime \prime} \mathrm{S}$ and Longitude: $39^{\circ} 22^{\prime}$ 30" W), and Itapé (Latitude: $14^{\circ} 53^{\prime}$ 54" S and Longitude: $39^{\circ} 25^{\prime} 16^{\prime \prime} \mathrm{W}$ ), all located in the south of Bahia, Brazil and belonging to the Atlantic Forest biome, with predominantly hot and humid tropical climate, between December 2016 and March 2017. The present study was approved by the Ethics Committee in Animal Experimentation at State University of Santa Cruz (CEUA - Universidade Estadual de Santa
Cruz - UESC), Ilheus, Bahia, Brazil, with protocol number 041/2016.

Forty-three Mangalarga Marchador stallions were divided into different categories: 1) age, subdivided into males up to six years old, seven to 11 years old, and over 12 years old; 2) sexual condition, subdivided into males in reproductive activity or sexual rest during the breeding season; 3) characteristics of sperm subdivided when presenting progressive motility greater or less than $60 \%$ and with a percentage of morphologically normal sperm greater or less than $70 \%$, to determine whether the scrotal thermographic profile could influence or be modified in any of these animal categories. Most of the stallions used in this research presented seminal parameters within the recommended range for equine species: gel free volume (40$60 \mathrm{~mL}$ ); color (grayish white); odor (sui generis); sperm motility ( $\geq 60)$; vigor $(\geq 3)$; and sperm concentration (> $100 \times 10^{6} / \mathrm{mL}$ ) (Manual..., 2013). In order to assess the influence of air temperature and relative humidity on the superficial temperature of the testicles and on seminal quality, only 30 stallions were selected.

The rectal temperature of all the stallions was measured using a clinical digital thermometer. Testicular biometry, according to the methodology described by Cruz et al. (2009), was measured to verify whether testicular size influenced scrotal temperature, considering the largest testicles have a greater heat dissipation surface. The stallions were transported individually from the pen to a flat, shady, and open area at the time of testicular measurements, capture of thermographic images, and semen collection. The obtained biometric data were used to calculate individual testicular volume and total testicular volume, according to the methodology described by Chenier (2007).

To determine the superficial scrotum temperature, a digital infrared thermography device was used, Thermovisor FLIR E60bx, at the moment of semen collection. The temperatures were obtained by measuring seven distinct points on the scrotal surface of both testicles: two points in the proximal zone (PZT), three points in the middle zone (MZT), and two points in the distal zone of each testicle (DZT). Then, the total surface temperature of the testicles was determined (TSTT; Figure 1). The 
thermograms were analyzed using the FLIR Tools® software (version 5.12.17023.2001) according to the methodology described by Ramires-Neto et al. (2013). Semen collection was performed using a proper artificial vagina, followed by an evaluation of macroscopic and microscopic parameters (Manual..., 2013), with assessment of the functional integrity of the plasma membrane according to the protocol described by Melo and Henry (1999).

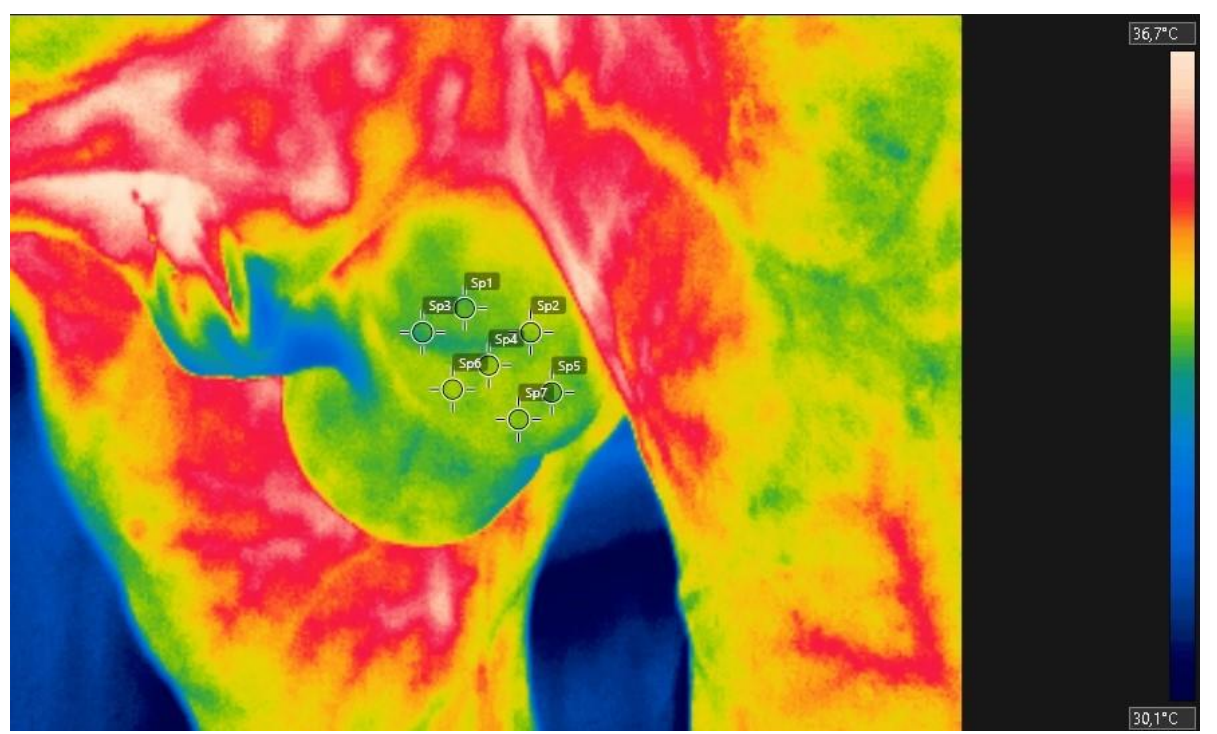

Figure 1. Image captured by FLIR E60bx thermal imager from Mangalarga Marchador stallion scrotum. Points assessed by the FLIR Tools ${ }^{\circledR}$ software to determine the testicular areas in the scrotum - Sp1 and $\mathrm{Sp} 2$ - points attributed to the proximal zone of the testis (PZT), Sp3, Sp4 and Sp5 - points attributed to the middle zone of the testis (MZT) and Sp6 and Sp7 - points assigned to the distal zone of the testis (DZT).

Simultaneously to semen collection and evaluation of scrotal thermography, air temperature (AT; ${ }^{\circ} \mathrm{C}$ ) and relative humidity $(\mathrm{RH}$; $\%)$ with automatic $\mathrm{HOBO}^{\circledR} \mathrm{U} 10-003$ sensors were measured. These evaluations were always performed in the morning, between 08:00 and 12:00. From these data, the temperaturehumidity index was calculated as $(\mathrm{THI}=(1.8 \times$ $\mathrm{AT}+32)-[(0.55-0.0055 \times \mathrm{RH}) \times(1.8 \times \mathrm{AT}-$ 26)] (Berry et al., 1964).

Data on average air temperature and relative humidity were obtained $1,5,9,33$, and 66 days before semen collection to verify the effects of environmental variables on the spermatogenic cycle and characteristics of ejaculates. It is a known fact that a new sperm population may be ejaculated approximately every 64 to 66 days, therefore, the average duration of spermatogenesis in equines of 57 days (Johnson, 1991); the epididymal transit period between five and nine days; and half the cycle, around 33 days were considered. Meteorological data were obtained from the meteorological station of the Research Center of the Cacau/Executive
Committee of the Cocoa Crops Plan (CEPEC/CEPLAC).

The thermographic profiles, environmental variables, and seminal and testicular parameters of Mangalarga Marchador stallions were considered for the analysis. All variables were expressed as mean \pm standard error. The data were examined for normality by the Shapiro-Wilk test and homoscedasticity by the Levene test, followed by an analysis of variance (ANOVA). To verify the existence of a difference in the thermographic profile between the three categories (age, sexual condition, and characteristics of the ejaculate), Tukey's test was performed. Mann's Whitney and Kruskal Wallis tests were applied to variables with violation of ANOVA assumptions. To verify the correlation between the thermographic profile, the seminal characteristics, testicular volume, and effect of meteorological variables (air temperature and relative humidity), Pearson and Spearman's correlation tests were performed on the data with parametric and non-parametric behavior, respectively. Correlations between 0.10 and 0.30 
were considered weak, between 0.40 and 0.60 moderate and above 0.70 strong. The level of significance was set at $5 \%$. All analyses were performed using IBM SPSS Statistics SPSS software, version 23.0.

\section{RESULTS}

There were no differences in average of testicular temperature per zone: proximal (PZT), médium (MZT), distal (DZT) and total superficial temperature of the testicles (TSTT) among the three studied categories (Table 1; $\mathrm{P}>0.05)$. All testicular zones and the TSTT presented a lower temperature between 3 and $4{ }^{\circ} \mathrm{C}$ when compared to the average rectal temperature of $37.8^{\circ} \mathrm{C}$ in all stallions $(n=43)$. This difference was of $3.9^{\circ} \mathrm{C}$ for the PZT; $3.8^{\circ} \mathrm{C}$ for MZT; $3.9^{\circ} \mathrm{C}$ for DZT and $3.9^{\circ} \mathrm{C}$ for TSTT. The scrotal temperature was approximately $34^{\circ} \mathrm{C}$. Environment variables, mean air temperature $\left({ }^{\circ} \mathrm{C}\right)$, relative humidity $(\%)$ and THI taken on the day of semen collection (day 0 ) and 1, 5, 9, 33 and 66 days before semen collection are presented in Table 2. The seminal characteristics, functional integrity of sperm membranes, total scrotal width (TSW) and total testicular volume (TTV) did not vary among the 30 studied stallions (Table 3).

Correlations were not found between the environmental variables and none of the seminal characteristics or testicular measurements. The TSTT evaluated at the moment of semen collection did not show correlation with the volume of the ejaculate, progressive motility, vigor, sperm concentration per $\mathrm{mL}$, percentage of major defects, total scrotal width and total testicular volume. However, the TSTT presented moderate and positive correlation with the minor defects $(\mathrm{R}=0.41 ; \mathrm{P}<0.05)$ and with total defects $(\mathrm{R}=0.46 ; \mathrm{P}<0.01)$. Nevertheless, a moderate and negative correlation was identified with the percentage of normal sperm $(\mathrm{R}=-0.46 ; \mathrm{P}<0.05$; Table 4).

Table 1. Mean values and standard deviation of temperature in testicular zones and rectal temperature of Mangalarga Marchador stallions with different ages, sexual conditions and semen characteristics in terms of progressive motility and morphologically normal sperm

\begin{tabular}{|c|c|c|c|c|c|}
\hline Age (years) & PZT $\left({ }^{\circ} \mathrm{C}\right)$ & $\operatorname{MZT}\left({ }^{\circ} \mathrm{C}\right)$ & $\operatorname{DZT}\left({ }^{\circ} \mathrm{C}\right)$ & $\operatorname{TSTT}\left({ }^{\circ} \mathrm{C}\right)$ & $\mathrm{RT}\left({ }^{\circ} \mathrm{C}\right) *$ \\
\hline$\leq 6$ & $33.9 \pm 0.7$ & $33.9 \pm 0.8$ & $33.9 \pm 1.0$ & $33.9 \pm 0.8$ & $37.9 \pm 0.4$ \\
\hline 7 to 11 & $33.8 \pm 0.8$ & $34.0 \pm 0.8$ & $33.9 \pm 0.8$ & $33.9 \pm 0.8$ & $37.7 \pm 0.4$ \\
\hline$\geq 12$ & $34.2 \pm 1.1$ & $34.2 \pm 1.2$ & $34.4 \pm 1.2$ & $34.2 \pm 1.1$ & $37.7 \pm 0.3$ \\
\hline Activity & $33.7 \pm 0.8$ & $33.8 \pm 0.8$ & $33.9 \pm 0.7$ & $33.8 \pm 0.7$ & $37.8 \pm 0.4$ \\
\hline Rest & $34.0 \pm 0.8$ & $34.1 \pm 0.9$ & $34.0 \pm 1.1$ & $34.0 \pm 0.9$ & $37.8 \pm 0.4$ \\
\hline$>60 \%$ motility & $33.8 \pm 0.7$ & $34.0 \pm 0.7$ & $34.0 \pm 0.7$ & $34.0 \pm 0.7$ & $37.8 \pm 0.4$ \\
\hline$\leq 70 \%$ normal & $33.9 \pm 1.0$ & $34.1 \pm 1.0$ & $34.0 \pm 1.0$ & $34.0 \pm 1.0$ & $37.8 \pm 0.3$ \\
\hline$>70 \%$ normal & $33.9 \pm 0.7$ & $33.9 \pm 0.8$ & $33.9 \pm 0.9$ & $33.9 \pm 0.7$ & $37.9 \pm 0.5$ \\
\hline
\end{tabular}

Testicle zones: proximal (PZT), middle (MZT), distal (DZT) and total surface temperature of the testicle (TSTT) and rectal temperature at the time of semen collection $(\mathrm{RT})^{*}$

Table 2. Minimum, average and maximum values of the average air temperature (AT; ${ }^{\circ} \mathrm{C}$ ), relative humidity $(\mathrm{RH} ; \%)$ and temperature and humidity index (THI) collected during the experiment

\begin{tabular}{|c|c|c|c|c|c|c|}
\hline \multirow{3}{*}{$\begin{array}{c}\text { Days before semen } \\
\text { collection }\end{array}$} & \multicolumn{6}{|c|}{ Environmental variable } \\
\hline & \multicolumn{2}{|c|}{$\operatorname{AT}\left({ }^{\circ} \mathrm{C}\right)$} & \multicolumn{2}{|c|}{$\mathrm{RH}(\%)$} & \multicolumn{2}{|c|}{ THI } \\
\hline & Mean & Range & Mean & Range & Mean & Range \\
\hline 66 days & 26.0 & $22.5-31.8$ & 81.8 & $79.5-83.8$ & 76.8 & $75.3-76.5$ \\
\hline 33days & 25.9 & $22.7-31.0$ & 84.9 & $81,5-89.5$ & 76.8 & $34,6-77,4$ \\
\hline 9 days & 25.5 & $21.7-30,7$ & 82.6 & $76,0-94,3$ & 75.9 & $34.8-77.3$ \\
\hline 5 days & 25.4 & $21.3-30.7$ & 82.6 & $78,3-89,5$ & 75.8 & $33.5-75.5$ \\
\hline
\end{tabular}


Table 3. Seminal characteristics, total scrotal width and volume of Mangalarga Marchador stallions

\begin{tabular}{|c|c|c|c|c|}
\hline \multirow{3}{*}{ Evaluated parameters } & & \multicolumn{3}{|c|}{ Age (years) } \\
\hline & All stallions & $\leq 6$ & 7 to 11 & $\geq 12$ \\
\hline & \multicolumn{4}{|c|}{ Average $\pm \mathrm{DP}$} \\
\hline Volume $(\mathrm{mL})$ & $54.0 \pm 35.0$ & $50.7 \pm 27.1$ & $47.5 \pm 16.7$ & $76.0 \pm 70.3$ \\
\hline Color & \multicolumn{4}{|c|}{ Grayish white to ivory white } \\
\hline Odor & \multicolumn{4}{|c|}{ Sui generis } \\
\hline Aspect & \multicolumn{4}{|c|}{ Watery to milky } \\
\hline Total motility (\%) & $69.0 \pm 12.2$ & $69.3 \pm 12.7$ & $67.0 \pm 12.5$ & $74.0 \pm 11.4$ \\
\hline Progressive motility (\%) & $63.0 \pm 13.4$ & $63.0 \pm 13.3$ & $62.0 \pm 16.0$ & $67.0 \pm 9.8$ \\
\hline Vigor & $3.0 \pm 0.4$ & $3.3 \pm 0.4$ & $3.3 \pm 0.4$ & $3.4 \pm 0.6$ \\
\hline Concentration $/ \mathrm{mL}\left(\mathrm{x} 10^{6} / \mathrm{mL}\right)$ & $205.0 \pm 109.9$ & $189.4 \pm 107.2$ & $231.8 \pm 123.3$ & $195.3 \pm 102.3$ \\
\hline Normal sperm (\%) & $78.0 \pm 7.9$ & $78.3 \pm 8.9$ & $78.0 \pm 7.9$ & $76.7 \pm 5.7$ \\
\hline Major defects (\%) & $9.4 \pm 4.0$ & $9.0 \pm 4.4$ & $8.8 \pm 3.9$ & $11.0 \pm 2.6$ \\
\hline Minor defects (\%) & $12.6 \pm 6.0$ & $12.6 \pm 6.6$ & $12.8 \pm 6.5$ & $12.1 \pm 3.7$ \\
\hline $\operatorname{HOST}(\%)^{*}$ & $65.0 \pm 13.6$ & $60.3 \pm 14.4$ & $70.30 \pm 8.4$ & $67.9 \pm 13.8$ \\
\hline Total scrotal width (cm) & $12.6 \pm 1.2$ & $12.3 \pm 1.2$ & $13.1 \pm 0.9$ & $12.4 \pm 1.4$ \\
\hline Total testicular volume $\left(\mathrm{cm}^{3}\right)$ & $416.9 \pm 113.6$ & $390.8 \pm 105.8$ & $465.9 \pm 114.7$ & $396.9 \pm 125.4$ \\
\hline
\end{tabular}

Table 4. Correlation among seminal parameters, average air temperature, relative humidity 1, 5, 9, 33 and 66 days before semen collection and the total surface temperature of the testicles of Mangalarga Marchador stallions $(\mathrm{n}=30)$

\begin{tabular}{|c|c|c|c|c|c|c|c|c|c|c|c|}
\hline \multirow[t]{2}{*}{ Parameters } & \multicolumn{2}{|c|}{66 days before } & \multicolumn{2}{|c|}{33 days before } & \multicolumn{2}{|c|}{9 days before } & \multicolumn{2}{|c|}{5 days before } & \multicolumn{2}{|c|}{1 day before } & \multirow{2}{*}{$\begin{array}{c}\begin{array}{c}\text { Semen } \\
\text { collection } \\
\text { day }\end{array} \\
\text { TSTT }\end{array}$} \\
\hline & AT & $\mathrm{RH}$ & AT & $\mathrm{RH}$ & AT & $\mathrm{RH}$ & AT & RH & AT & $\mathrm{RH}$ & \\
\hline PMot. & 0.09 & -0.18 & 0.19 & -0.07 & 0.04 & -0.01 & 0.01 & -0.05 & -0.12 & 0.00 & -0.07 \\
\hline Vigor & 0.07 & -0.01 & -0.08 & -0.13 & -0.16 & 0.07 & -0.01 & -0.04 & 0.22 & -0.15 & -0.07 \\
\hline [] $\times 10^{6} / \mathrm{mL}$ & 0.01 & -0.14 & -0.11 & -0.18 & -0.16 & 0.14 & 0.11 & -0.19 & 0.21 & -0.19 & 0.08 \\
\hline Minor Def. & -0.14 & 0.25 & 0.20 & -0.08 & -0.05 & 0.29 & 0.29 & 0.32 & -0.16 & 0.25 & $0.41 *$ \\
\hline Total Def. & 0.27 & 0.22 & 0.23 & -0.08 & -0.21 & -0.01 & -0.32 & 0.36 & -0.02 & 0.11 & $0.46 * *$ \\
\hline $\begin{array}{l}\text { Normal } \\
\text { sperm }\end{array}$ & -0.27 & -0.22 & -0.23 & 0.08 & 0.20 & -0.38 & -0.19 & -0.36 & 0.02 & -0.11 & $-0.46^{*}$ \\
\hline TTV & - & - & - & - & - & - & - & - & - & - & -0.01 \\
\hline TSW & - & - & - & - & - & - & - & - & - & - & -0.14 \\
\hline
\end{tabular}

$\mathrm{AT}=$ average air temperature; $\mathrm{RH}=$ relative humidity; TSTT = total surface testicle temperature.

PMot. - progressive motility; [] x10\%/mL- concentration, Major Def. - major defect; Minor Def. - minor defect; Total Def. - total defects. TTV - total testicular volume, TSW - total scrotal width.

*correlation $(\mathrm{P}<0.05)$, ** correlation $(\mathrm{P}<0.01)$.

\section{DISCUSSION}

For efficient spermatogenesis in equines, a testicular temperature between 3 and $4^{\circ} \mathrm{C}$ is required below the corporal temperature (Alvarenga and Papa, 2009). All studied stallions presented an average surface temperature approximately $3.9^{\circ} \mathrm{C}$ less than the rectal temperature of $37.8^{\circ} \mathrm{C}$. It is possible to suggest that these stallions, regardless of age, reproductive condition, and seminal parameters, presented a satisfactory thermoregulation mechanism, by means of cooling the arterial blood through the pampiniform plexus (Sorensen et al., 1991), associated with distention of tunica dartos fibers (Brinsko et al., 2011) and the cremaster muscle (Setchell, 1991), and also related to the secretory cells of the apocrine glands present in the skin of the scrotum (Yasui et al., 2006).

The similarity between thermographic profiles obtained in males of different categories showed that the Mangalarga Marchador breed is well adapted to climatic conditions of this region of the Atlantic Rainforest, considering that scrotal temperature was close to $34^{\circ} \mathrm{C}$, similar to that described by Ramires-Neto et al. (2013) in Quarter Horse stallions. In addition, similar thermoregulation capacity among animals of different ages observed in this study had already been described by Ramires-Neto et al. (2013) in 
young and sexually mature stallions and by Souza et al. (2017) who studied young and adult bulls. Based on these studies, it is possible to affirm that the ability to regulate testicular temperature occurs regardless of age. Out of the 43 evaluated stallions, 30 ejaculates were within physiological values for equines (Manual..., 2013), although 13 animals produced sperm motility between $44 \%$ and $59 \%$, vigor below 3 , and morphologically normal sperm below $69 \%$. It is important to highlight that variation in the percentage of progressively motile and morphologically normal sperm did not correlate with any testicular thermoregulation disorder related to the environment. Some stallions in the present study were in sexual rest, with sperm stored in the tail of epididymis for a long time, which has been shown to cause changes in parameters of sperm movement and increase in morphological changes, mainly on the sperm tail (Alvarenga and Papa, 2009).

Some of the evaluated stallions were used weekly in horseback riding or walking tests. According to Janett et al. (2006), physical activity of high intensity negatively influences sperm quality, resulting in reduction of motility and increase in major sperm defects. Such practice would result in physical stress with elevation of circulating glucorticosteroids and increase in transient testicular temperature that would compromise testicular thermoregulation (Staempfli et al., 2006). It has been reported that equine sperm motility was also slightly affected by scrotal temperature (Lloyd-Jones et al., 2015). Although, thermograms of all evaluated animals were within the expected range for the species, scrotal surface temperature was around $34^{\circ} \mathrm{C}$, on the day of semen collection. For the correlations between seminal parameters, average environmental temperature, relative humidity 1 , $5,9,33$ and 66 days before semen collection, and TSTT, only data from 30 stallions were used that were considered satisfactory and had parameters within the physiological range for equines (Manual..., 2013). During the entire experimentation phase, which comprised a cycle of spermatogenesis and a period of sperm maturation, mean air temperature was $25.6^{\circ} \mathrm{C}$, which is within the recommended thermoneutral zone for horses from 5 to $25^{\circ} \mathrm{C}$ (Morgan, 1998). Average values of relative humidity between $81 \%$ and $84 \%$ were found to be elevated, since values above $70 \%$ may be harmful to most domestic species (Baêta and Souza, 2010). Air humidity is a highly relevant variable once it determines the effectiveness of heat loss mechanisms. High humidity environments hinder evaporative losses such as sweating and breathing, which are the main equine thermolysis pathways (Marlin et al., 2018). Such conditions may improve the elevation of body temperature; however, the evaluated animals did not present changes in rectal temperature $\left(37.8^{\circ} \mathrm{C}\right)$ in order to negatively impact the spermatogenic process.

At the time of collection, which occurred between 8:00 and 12:00 in the morning, environmental variables (AT: $31.4^{\circ} \mathrm{C}$; RH: $68.3 \%$ and THI: 82.8 ) characterized a thermal stress condition. As proposed by Baêta and Souza (2010), a thermal comfort condition is found when the THI value is 70 , values between 71 and 78 characterize a critical situation, between 79 and 83 is a danger sign, and above 84 is considered an emergency. Such values indicate dangerous conditions for stallions. The intensity and duration of the stressor are essential for animals to trigger mechanisms of physiological or behavioral adjustments. When these mechanisms are efficient, adaptation responses cause individuals to perform their role normally (Hahn, 1993). The animals were exposed to such environments for a short period of time, approximately 10 to 15 minutes during semen collection and obtaining thermograms images. This time was not sufficient to generate a stress condition that had a negative influence on the average temperature of the PZT, MZT, DZT, and TSTT.

Although the effects of high temperature and humidity in sperm production and quality are established and vastly reported in literature (Souza et al., 2015; Ahirwar et al., 2018), such effects were not evidenced here, which may suggest that the animals in these conditions were adapted to local conditions. Correlations between TSTT and minor defects, and TSTT and total defects were positive and moderate. Furthermore, correlation between TSTT and morphologically normal sperm was negative and moderate. These data are similar to those reported by Ramires-Neto et al. (2013), who observed that an increase in testicular temperature increases the occurrence of morphological changes in equine sperm, as also 
evidenced in ruminants (Souza et al., 2015; Menegassi et al., 2017; Ahirwar et al., 2018).

Any factor that interferes with thermoregulation mechanisms may compromise the maintenance of physiological testicular temperature for spermatogenesis. The increase in testicular temperature will lead to an increase in cellular metabolism with consequent increased need for tissue oxygen. Blood support to the testis is deficient; therefore, if oxygen is not available, cell death and free radical production occur. The sequence of appearance of sperm morphological defects in the ejaculate depends on the severity and time of injury to the testicles and may develop into a pathological case of testicular degeneration (Alvarenga and Papa, 2009). Thus, it is important that bioclimatic and sanitary conditions are suitable for providing thermal comfort and health to stallions in order to preserve the reproductive characteristics and generandi potency (Manual..., 2013).

\section{CONCLUSION}

Mangalarga Marchador stallions bred in the Atlantic Rainforest biome, regardless of age, reproductive activity, and seminal characteristics, presented testicular temperature around $34^{\circ} \mathrm{C}$, approximately $3.9^{\circ} \mathrm{C}$ less than corporal temperature, indicating that testicular thermoregulation mechanisms were effective under physiological conditions. The environment did not significantly influence testicular temperature or sperm quality in the study conditions; however, testicular temperature presented a negative and moderate correlation with the percentage of morphologically normal sperm.

\section{ACKNOWLEDGEMENTS}

The Foundation of Research Support in the State of Bahia (FAPESB, Salvador, BA, Brazil) and the State University of Santa Cruz (Ilhéus, Bahia, Brazil).

\section{REFERENCES}

AHIRWAR, M.K.; KATAKTALWARE, M.A.; PUSHPADASS, H.A. et al. Scrotal infrared digital thermography predicts effects of thermal stress on buffalo (Bubalus bubalis) semen. $J$. Therm. Biol., v.78, p.51-57, 2018.
ALVARENGA, M.A.; PAPA, F.O. Principais distúrbios reprodutivos observados em garanhões no Brasil. Rev. Bras. Reprod. Anim. Supl., n. 6, p.204-209, 2009.

BAÊTA, F.C.; SOUZA, C.F. Ambiência em edificações rurais: conforto animal. 2.ed. Viçosa: UFV, 2010. 269p.

BERRY, I.L.; SHANKLIN, N.D.; JOHNSON, H.D. Dairy shelter design based on milk production decline as affected by temperature and humidity. Trans. ASAE, v.7, p.329-331, 1964.

BRINSKO, S.P.; BLANCHARD, T.L.; VARNER, D.D. et al. Reproductive physiology of the nonpregnant mare. In: BRINSKO, S.P. (Ed.). Manual of equine reproduction. 3.ed. Maryland Heights: Mosby Elsevier, 2011. p.242275.

CHENIER, T.S. Anatomy and examination of the normal testicle. In: SAMPER, J.C.; PYCOCK, J.F.; MCKINNON, A.O. (Eds.). Current therapy in equine reproduction. USA: Saunders, 2007. Cap.26. p.167-168.

CRUZ, A.C.B.; BORGES, G.S.; MELO, M.I.V. et al. Biometria testicular em garanhões Mangalarga Marchador. Rev. Bras. Med. Vet., v.31, p.30-34, 2009.

HAHN, G.L. Bioclimatologia e instalações zootécnicas: aspectos teóricos e aplicados. In: WORKSHOP BRASILEIRO DE BIOCLIMATOLOGIA ANIMAL, 2., 1993, Jaboticabal. Anais.... Jaboticabal: FUNEP 1993. p.132-146. (Boletim H148b).

JANETT, F.; BURKHARDT, C.; BURGER, D. et al. Influence of repeated treadmill exercise on quality and freezability of stallion semen. Theriogenology, v.65, p.1737-1749, 2006.

JOHNSON, L. Spermatogenesis. In: CUPPS, P.T, (Ed.). Reproduction in domestic animals. San Diego: Wiley, 1991. p.173-219.

KASTELIC, J.P.; COOK, R.B.; COULTER, G.H. et al. Environmental factors affecting measurement of bovine scrotal surface temperature with infrared thermography. Anim. Reprod. Sci., v.41, p.153-159, 1996.

LACETERA, N. Impact of climate change on animal health and welfare. Anim. Front., v.9, p.26-31, 2019. 
LEES, A.M.; SEJIAN, V.; WALLAGE, L.A. et al. The impact of heat load on cattle. Animals. Animals, v.9, p.322, 2019.

LLOYD-JONES, J.L.; PUROHIT, R.C.; BOYLE, M. et al. Use of thermography for functional evaluation of stallion scrotum and testes. J. Equine Vet. Sci., v.35, p.488-494, 2015.

MANUAL para exame andrológico e avaliação do sêmen animal. 3.ed. Belo Horizonte: CBRA, 2013. 104p.

MARLIN, D.; MISHEFF, M.; WHITEHEAD, P. Preparation for and management during equestrian events held in thermally challenging environments. FEI, 2018. Available in: https://www.sponet.de/Record/4057288.

Accessed in: 10 Aug. 2020.

MELO, M.I.V.; HENRY, M. Teste hiposmótico na avaliação de sêmen equino. Arq. Bras. Med. Vet. Zootec., v.51, p.71-78, 1999.

MENEGASSI, S.R.O.; PEREIRA, G.R.; DIAS, E.A. et al. Infrared thermography as a noninvasive method to assess scrotal insulation on sperm production in beef bulls. Andrologia, v.50, p.2-8, 2017

MORGAN, K. Thermoneutral zone and critical temperatures of horses. J. Therm. Biol., v.23, p.59-61, 1998.

RAMIRES NETO, C.; MONTEIRO, G.A.; DELFIOL, D.J.Z. et al. The relationships between scrotal surface temperature, age and sperm quality in stallions. Livest. Sci., v.157, p.358-363, 2013.
SETCHELL, B.P. Male reproductive organs and semen. In: CUPPS, P.T. (Ed.). Reproduction of domestic animals. New York: Academic Press, 1991. p.221-249.

SORENSEN, H.G.; LAMBRECHTSEN, J.; EINER-JENSEN, N. Efficiency of the countercurrent transfer of heat and 133Xenon between the pampiniform plexus and testicular artery of the bull under in-vitro conditions. Int. J. Androl., v.14, p.232-240, 1991.

SOUZA, C.D.; CHACUR, M.G.M.; RUEDIGER, F.R. et al. Influência dos fatores climáticos não sêmen de touros Nelore (Bos Touro indicus). Colloq. Agrar., v.11, p.81-87, 2015.

SOUZA, C.D.; CHACUR, M.G.M.; RUEDIGER, F.R. et al. Temperatura por infravermelho do escroto e quadro seminal em touros adultos jovens e adultos maduros da raça nelore. Colloq. Agrar., v.13, p.66-70, 2017.

STAEMPFLI, S.; JANETT, F.; BURGER, D. et al. Effect of exercise and suspensory on scrotal surface temperature in the stallion. Theriogenology, v.66, p.2120-2126, 2006.

VIEIRA, J.I.T.; SILVA, T.A.; BARBOSA, W.M.P. et al. Influência da temperatura sobre a função testicular. Med. Vet., v.12, p.62-72, 2018.

YASUI, T.; TSUKISE, A.; MIURA, T. et al. Cytochemical characterization of glycoconjugates in the apocrine glands of the scrotal skin. Arch. Histol. Cytol., v.69, p.109$117,2006$. 